\title{
Hubungan Antara Profitabilitas Terhadap Earnings Management pada Sektor Utama Indonesia di BEI Tahun 2008-2011
}

\author{
Cindy Kristina Hariyono \\ Akuntansi / Fakultas Bisnis dan Ekonomika \\ ckristina67@gmail.com
}

\begin{abstract}
Abstrak - Perusahaan yang mengalami kerugian memiliki kecenderungan melakukan upaya yang dapat memberikan manfaat bagi perusahaan, salah satunya dengan melakukan earnings management. Penelitian ini bertujuan untuk mengetahui hubungan antara profitabilitas terhadap earnings management pada perusahaan yang mengalami kerugian saat krisis ekonomi Eropa. Populasi dalam penelitian ini adalah seluruh perusahaan di 9 sektor utama yang terdaftar di BEI dan memiliki net income negatif pada tahun 2008-2011. Perhitungan profitabilitas dalam penelitian ini menggunakan variabel ROA, OPM, DE, OCF, dan Size, sedangkan pendeteksian earnings management menggunakan discretionary accruals dengan menggunakan model Jones (1991). Hasil penelitian ini menunjukkan bahwa terdapat 2 sektor utama yang melakukan earnings management pada saat mengalami kerugian, sedangkan 7 sektor lainnya tidak melakukan earnings management pada saat mengalami kerugian.
\end{abstract}

Kata kunci : profitabilitas, earnings management, krisis ekonomi, sektor utama

\begin{abstract}
Losses' companies have a tendency to make efforts that could provide benefits for the company, one of them by performing an earnings management. This study aims to determine the relationship between the profitability of the earnings management practices in the companies have losses during the economic crisis of Europe. The population in this study are all companies in 9 major sectors listed on the BEI and have a negative net income in 2008-2011. For calculate of profitability in this study using ROA, OPM, DE, OCF, and Size, while for detecting earnings management using discretionary accruals by using the model of Jones (1991). These results indicate that there are two main sectors that perform earnings management when the companies have losses, while the other sectors did not perform earnings management when they have losses.
\end{abstract}

Keywords : profitability, earnings management, the economic crisis, main sector

\section{PENDAHULUAN}

Ketika terjadi krisis ekonomi, perusahaan di berbagai negara cenderung menerapkan alternatif lain dalam metode akuntansi, karena adanya berbagai motivasi untuk dapat mempengaruhi output dengan cara tertentu sesuai dengan kebutuhan perusahaan (Fields dan Vincent, 2001). Selain itu, menurut Dimitropoulos dan Asteriou (2010) menyatakan ketika perusahaan berada di bawah tekanan ekonomi, maka perusahaan akan termotivasi untuk membuat 
pilihan akuntansi yang dapat memperkuat kinerja dan posisi keuangannya. Krisis ekonomi global juga dapat mempengaruhi kebijakan yang diambil oleh pihak manajemen didalam menyusun laporan keuangan yang dapat mempengaruhi penilaian terhadap perusahaan (Adiasih dan Kusuma, 2011).

Nurim dan Kusuma (2001) menyatakan bahwa laba merupakan salah satu alat untuk mengukur kinerja perusahaan. Laba juga merupakan alat untuk menyampaikan informasi mengenai tanggung jawab manajemen terhadap pengelolaan sumber daya. Maka dari itu, berbagai upaya akan dilakukan oleh pihak manajemen untuk dapat meningkatkan / mengurangi laba tersebut, salah satunya dengan melakukan manajemen laba (earnings management). Praktik earnings management timbul karena pasar pada umumnya tidak dapat menerima kenyataan bahwa perusahaan mengalami kerugian, sehingga pada saat terjadi krisis ekonomi keterlibatan perusahaan diberbagai negara untuk melakukan earnings management akan semakin tinggi (Levitt, 1998).

DeAngelo et al. (1994) menyimpulkan bahwa manajer dari perusahaan yang mengalami kerugian cenderung akan memanipulasi laporan keuangan untuk menyembunyikan masalah keuangan yang sebenarnya dihadapi oleh perusahaan. Rosner (2003) menunjukkan bahwa manajer dari suatu perusahaan yang mengalami kerugian akan melakukan manajemen laba untuk mendapatkan unqualified opinion dari auditor. Badan usaha yang mengalami kerugian umumnya akan segera mengambil tindakan untuk merespon kondisi tersebut dengan cara melakukan earnings management (Fachruddin, 2008). Namun, Filip dan Raffournier (2012) menyimpulkan bahwa praktik earnings management tidak dilakukan oleh semua negara pada saat terjadi krisis ekonomi yang menyebabkan perusahaan tersebut mengalami kerugian.

Pada penelitian sebelumnya yang dilakukan oleh Selahudin, dkk. (2014) menunjukkan bahwa perusahaan-perusahaan di Asia Tenggara, seperti di Thailand dan Malaysia terdapat hubungan antara profitabilitas dengan earnings management, karena saat perusahaan mengalami kerugian pada tahun 2009-2012, dimana pada tahun tersebut terjadi krisis ekonomi Eropa ikut melakukan earnings management. Hasil penelitian juga menunjukkan bahwa kecenderungan perusahaan di Thailand lebih tinggi untuk melakukan earnings management 
dibandingkan Malaysia. Tetapi, hasil penelitian ini berbeda dengan penelitian yang dilakukan oleh Iatridis dan Dimitras (2013) yang menunjukkan bahwa tidak terdapat hubungan antara profitabilitas dengan earnings management, seperti perusahaan di Irlandia, Italia, dan Spanyol yang mengalami kerugian saat terjadi krisis ekonomi Eropa justru tidak ikut melakukan earnings management.

Krisis ekonomi Eropa tentu membawa dampak negatif bagi perekonomian Indonesia (Bank Indonesia, 2008), dikarenakan Eropa memegang peranan yang cukup penting untuk memajukan kondisi ekonomi Indonesia. Terbukti, pada saat terjadi krisis ekonomi Eropa, yaitu pada tahun 2008-2011 volume perdagangan ekspor impor Indonesia cenderung mengalami penurunan dan Indeks Harga Saham Gabungan (IHSG) pada bulan Desember 2008 ditutup pada 1.355,4, yang mengalami penurunan hampir setengah dari tingkat di awal tahun 2008, yaitu sebesar 2.627,3. Selain itu, juga terjadi penurunan cukup tajam dalam volume perdagangan saham, karena pasar juga bereaksi terhadap berita kondisi eksternal. Hal ini disebabkan, karena perekonomian Indonesia yang semakin terbuka, sehingga sangat rentan terhadap ketidakpastian kondisi eksternal.

Berdasarkan hasil penelitian sebelumnya yang menunjukkan bahwa ternyata di Asia Tenggara, seperti perusahaan di Malaysia dan Thailand yang mengalami kerugian saat terjadi krisis ekonomi Eropa juga ikut melakukan earnings management, maka peneliti akan melakukan penelitian ini di Indonesia untuk melihat lebih lanjut hubungan antara profitabilitas terhadap earnings management pada saat krisis ekonomi Eropa tahun 2008-2011 dengan melihat pada 9 sektor utama perusahaan di Indonesia, yaitu sektor pertanian, sektor pertambangan, sektor industri dasar dan kimia, sektor aneka industri, sektor barang konsumsi, sektor properti dan perumahan, sektor infrastruktur, utilitas, dan transportasi, sektor keuangan, serta sektor perdagangan, jasa, dan investasi.

\section{METODE PENELITIAN}

Dengan adanya perbedaan dari hasil penelitian sebelumnya yang telah dilakukan oleh Selahudin, dkk. (2014) serta Iatridis dan Dimitras (2013), maka peneliti akan melakukan penelitian ini di Indonesia dengan melihat dari 9 sektor utama dengan membuat rancangan hipotesis di bawah ini : 
H1 : Profitabilitas berhubungan dengan earnings management pada perusahaan yang mengalami kerugian pada setiap sektor utama.

Dimana hipotesis 1a untuk sektor aneka industri, hipotesis 1b untuk sektor barang konsumsi, hipotesis 1c untuk sektor industri dasar dan kimia, hipotesis 1d untuk sektor infrastruktur, utilitas, dan transportasi, hipotesis 1e untuk sektor keuangan, hipotesis 1f untuk sektor perdagangan, jasa, dan investasi, hipotesis 1g untuk sektor pertambangan, hipotesis $1 \mathrm{~h}$ untuk sektor pertanian, dan hipotesis $1 \mathrm{i}$ untuk sektor properti dan perumahan.

Untuk mengetahui hubungan antara profitabilitas terhadap earnings management, penelitian ini menggunakan model regresi berganda dari Arellano dan Bond (1991) dalam Dimitras, dkk. (2015) :

DAi,t $=\alpha_{0}+\alpha_{1}$ ROAi,t $+\alpha_{2}$ OPMi,t $+\alpha_{3}$ SIZEi,t $+\alpha_{4}$ OCFi,t $+\alpha_{5}$ DEi,t + ei,t

Hipotesis akan diterima jika profitabilitas berhubungan dengan earnings management pada perusahaan yang mengalami kerugian pada 9 sektor utama Indonesia di BEI pada tahun 2008-2011, sedangkan hipotesis akan ditolak jika profitabilitas tidak berhubungan dengan earnings management.

Untuk mendeteksi adanya earnings management digunakan variabel discretionary accruals yang menggunakan model Jones (1991) :

DAi,t $=\left[\alpha_{0}\left(\frac{1}{\text { Ail }, \mathbf{t}-1}\right)+\alpha_{1} \Delta \mathrm{REVi,t}+\alpha_{2}\right.$ PPEi,t + ei,t $]-\mathrm{NDA}$ dimana :

DAi,t : discretionary accruals perusahaan i pada periode t.

Ai,t-1 : : total aset perusahaan i pada periode sebelumnya.

$\triangle \mathrm{REVi}, \mathrm{t} \quad$ : perubahan jumlah pendapatan perusahaan i dibagi dengan total aset periode sebelumnya.

PPEi,t : property, plant, and equipment perusahaan i dibagi dengan total aset periode sebelumnya.

ei,t : error term.

NDA : non discretionary accruals.

Variabel independen yang digunakan dalam penelitian ini adalah Return On Asset (ROA) yang dihitung dari net income dibagi dengan total aset perusahaan. Selain itu, beberapa variabel kontrol yang digunakan adalah Operating Cash Flow (OCF) yang dihitung melalui arus kas bersih yang 
dihasilkan dari kegiatan operasi perusahaan dibagi dengan total aset, Size (SIZE) yang dapat dihitung melalui nilai logaritma market value perusahaan, Operating Profit Margin (OPM) dihitung dari EBIT dibagi dengan total penjualan, Debt to Equity (DE) yang dihitung dari total liabilitas dibagi dengan total ekuitas.

Target dan populasi yang digunakan dalam penelitian ini adalah 9 sektor utama perusahaan yang terdaftar di BEI yang memiliki net income negatif pada tahun 2008-2011. Pada penelitian ini, teknik pengambilan sampel menggunakan judgement sampling dimana pengambilan sampel berdasarkan kriteria tertentu, yaitu perusahaan harus memiliki laporan keuangan yang telah diaudit pada tahun 2008-2011dan laporan keuangan harus disajikan dengan mata uang Rupiah.

Prosedur pengumpulan data dilakukan dengan : 1) menentukan dan membuat daftar seluruh sektor utama perusahaan yang terdaftar di BEI pada tahun 2008-2011 yang memiliki net income negatif melalui www.idx.co.id, 2) mengambil data laporan keuangan yang telah diaudit pada tahun 2008-2011 pada perusahaan yang memiliki net income negatif, 3) melakukan pengambilan sampel sesuai dengan kriteria sampel yang telah ditetapkan, 4) mencari dan mengumpulkan data - data terkait variabel yang dibutuhkan, seperti ROA, operating profit margin, operating cash flow, debt to equity, dan size.

\section{HASIL DAN PEMBAHASAN}

Tabel 1 menunjukkan proses pemilihan sampel. Berdasarkan kriteria pemilihan sampel diperoleh jumlah sampel sebanyak 231 perusahaan dari seluruh sektor utama pada tahun 2008-2011.

\section{Tabel 1. Pemilihan Sampel}

\begin{tabular}{|c|c|c|c|c|c|}
\hline \multirow{2}{*}{ Keterangan } & \multicolumn{4}{|c|}{ Tahun } & \multirow{2}{*}{$\begin{array}{c}\text { Jumlah } \\
\text { Perusahaan }\end{array}$} \\
\hline & 2008 & 2009 & 2010 & 2011 & \\
\hline $\begin{array}{l}\text { Jumlah perusahaan di seluruh sektor } \\
\text { utama yang memiliki net income } \\
\text { negatif }\end{array}$ & 88 & 61 & 51 & 60 & 260 \\
\hline $\begin{array}{l}\text { Perusahaan yang tidak memiliki } \\
\text { laporan keuangan yang telah diaudit }\end{array}$ & -11 & -2 & -2 & -3 & -18 \\
\hline $\begin{array}{l}\text { Laporan keuangan yang disajikan } \\
\text { tidak menggunakan mata uang } \\
\text { Rupiah }\end{array}$ & -3 & -2 & -2 & -4 & -11 \\
\hline Total & 74 & 57 & 47 & 53 & 231 \\
\hline
\end{tabular}


Tabel 2 menyajikan hasil dari statistik deskriptif untuk seluruh sampel dari 9 sektor utama di Indonesia. Nilai rata-rata dari discretionary accruals adalah 807,782688 dengan standar deviasi sebesar 2579,0284. Hal tersebut menunjukkan bahwa perusahaan sampel mempunyai variasi yang rendah dalam melakukan earnings management. Nilai minimum dari discretionary accruals sebesar 911,7490 dimiliki oleh PT Davomas Abadi dari sektor barang konsumsi, sedangkan nilai maksimum sebesar 26484,7671 dimiliki oleh PT Excelcomindo Pratama dari sektor infrastruktur, utilitas, dan transportasi.

Tabel 2. Statistik Deskriptif

Descriptive Statistics

\begin{tabular}{|c|c|c|c|c|c|}
\hline & $\mathrm{N}$ & Minimum & Maximum & Mean & Std. Deviation \\
\hline DA & 231 & -911.7490 & 26484.7671 & 807.782688 & $2.5790284 \mathrm{E} 3$ \\
\hline DE & 231 & -41.0000 & 207.1000 & 2.591758 & 16.5597061 \\
\hline Size & 231 & .0000 & 3.6990 & 2.221037 & .4726120 \\
\hline OCF & 231 & $\begin{array}{c}- \\
1.0741781000\end{array}$ & 1.0820832000 & .013268924163 & .1764409273178 \\
\hline ROA & 231 & -125.5000 & -.0003 & -.671463 & 8.2511150 \\
\hline OPM & 231 & -2222.00 & 1753.00 & -20.3102 & 274.61441 \\
\hline $\begin{array}{ll}\text { Valid } & N \\
\text { (listwise) }\end{array}$ & 231 & & & & \\
\hline
\end{tabular}

Variabel return on asset memiliki nilai minimum sebesar -125,5 yang dimiliki oleh PT Hanson International dari sektor aneka industri, sedangkan nilai maksimum sebesar -0,0003 dimiliki oleh PT Leyand International dari sektor infrastruktur, utilitas, dan transportasi. Pembahasan hasil statistik deskriptif di atas sebagian besar menunjukkan bahwa nilai standar deviasi lebih besar dibandingkan dengan nilai rata-ratanya. Nilai standar deviasi yang lebih besar ini menunjukkan bahwa adanya kesenjangan yang besar antara nilai minimum dan nilai maksimum, sehingga dapat dikatakan bahwa nilai dari distribusi data tersebut telah menyimpang jauh dari nilai rata-ratanya.

Hasil dari korelasi Pearson dapat dilihat pada tabel 3. Uji koefisien korelasi dilakukan dengan tujuan untuk menunjukkan keeratan hubungan antara 2 variabel, yaitu variabel dependen dan variabel independen. Jika nilai semakin mendekati 1 atau -1, maka hubungannya akan semakin erat dan jika mendekati 0 , maka hubungannya akan semakin lemah. 
Tabel 3. Koefisien Korelasi Pearson

\begin{tabular}{|c|c|c|c|}
\hline Sektor Utama & Korelasi & $\begin{array}{c}\text { Pearson } \\
\text { Correlation }\end{array}$ & Sig. (2-tailed) \\
\hline \multirow{5}{*}{ Aneka Industri } & DA dan ROA & 0,160 & 0,317 \\
\hline & DA dan OCF & $0,592 * *$ & 0,000 \\
\hline & DA dan OPM & $-0,071$ & 0,660 \\
\hline & DA dan Size & 0,152 & 0,341 \\
\hline & DA dan DE & 0,038 & 0,815 \\
\hline \multirow{5}{*}{ Barang Konsumsi } & DA dan ROA & 0,405 & 0,367 \\
\hline & DA dan OCF & $-0,545$ & 0,206 \\
\hline & DA dan OPM & $-0,073$ & 0,877 \\
\hline & DA dan Size & $-0,637$ & 0,124 \\
\hline & DA dan DE & 0,231 & 0,618 \\
\hline \multirow{5}{*}{ Industri Dasar dan Kimia } & DA dan ROA & 0,219 & 0,254 \\
\hline & DA dan OCF & 0,329 & 0,081 \\
\hline & DA dan OPM & 0,145 & 0,452 \\
\hline & DA dan Size & 0,003 & 0,988 \\
\hline & DA dan DE & 0,191 & 0,322 \\
\hline \multirow{5}{*}{$\begin{array}{l}\text { Infrastruktur, Utilitas, dan } \\
\text { Transportasi }\end{array}$} & DA dan ROA & 0,094 & 0,570 \\
\hline & DA dan OCF & $0,363^{*}$ & 0,023 \\
\hline & DA dan OPM & $0,628 * *$ & 0,000 \\
\hline & DA dan Size & 0,238 & 0,144 \\
\hline & DA dan DE & $0,376 *$ & 0,018 \\
\hline \multirow{5}{*}{ Keuangan } & DA dan ROA & 0,223 & 0,359 \\
\hline & DA dan OCF & $-0,520 *$ & 0,022 \\
\hline & DA dan OPM & $-0,029$ & 0,907 \\
\hline & DA dan Size & $-0,059$ & 0,811 \\
\hline & DA dan DE & 0,111 & 0,650 \\
\hline \multirow{5}{*}{$\begin{array}{l}\text { Perdagangan, Jasa, dan } \\
\text { Investasi }\end{array}$} & DA dan ROA & 0,211 & 0,224 \\
\hline & DA dan OCF & 0,112 & 0,521 \\
\hline & DA dan OPM & 0,378* & 0,025 \\
\hline & DA dan Size & $0,346^{*}$ & 0,042 \\
\hline & DA dan DE & 0,201 & 0,248 \\
\hline \multirow{5}{*}{ Pertambangan } & DA dan ROA & 0,137 & 0,671 \\
\hline & DA dan OCF & 0,070 & 0,828 \\
\hline & DA dan OPM & 0,409 & 0,187 \\
\hline & DA dan Size & $-0,492$ & 0,105 \\
\hline & DA dan DE & $-0,287$ & 0,366 \\
\hline \multirow{5}{*}{ Pertanian } & DA dan ROA & 0,266 & 0,404 \\
\hline & DA dan OCF & 0,142 & 0,661 \\
\hline & DA dan OPM & $-0,006$ & 0,985 \\
\hline & DA dan Size & 0,424 & 0,170 \\
\hline & DA dan DE & $-0,537$ & 0,072 \\
\hline \multirow{5}{*}{ Properti dan Perumahan } & DA dan ROA & 0,150 & 0,422 \\
\hline & DA dan OCF & 0,204 & 0,271 \\
\hline & DA dan OPM & 0,126 & 0,499 \\
\hline & DA dan Size & 0,146 & 0,435 \\
\hline & DA dan DE & $-0,080$ & 0,699 \\
\hline
\end{tabular}


Korelasi antara DA dengan ROA pada 9 sektor utama di Indonesia menunjukkan bahwa terdapat hubungan yang lemah dan tidak signifikan. Hal ini menunjukkan bahwa profitabilitas tidak berhubungan kuat dengan earnings management, sehingga ada faktor / variabel lain yang lebih berhubungan dengan earnings management.

Tabel 4 menunjukkan hasil uji koefisien determinasi. Uji koefisien determinasi dilakukan untuk menguji kemampuan variabel independen (ROA) dan variabel kontrol (OPM, OCF, Size, dan DE) dalam menjelaskan variabel dependen (DA).

\section{Tabel 4. Koefisien Determinasi}

\begin{tabular}{|c|c|c|}
\hline Sektor Utama & Model Regresi & $\boldsymbol{R}$ Square \\
\hline Aneka Industri & DA & 0,286 \\
\hline Barang Konsumsi & DA & 0,721 \\
\hline Industri Dasar dan Kimia & DA & 0,334 \\
\hline Infrastruktur, Utilitas, dan Transportasi & DA & 0,236 \\
\hline Keuangan & DA & 0,623 \\
\hline Perdagangan, Jasa, dan Investasi & DA & 0,518 \\
\hline Pertambangan & DA & 0,585 \\
\hline Pertanian & DA & 0,956 \\
\hline Properti dan Perumahan & DA & 0,631 \\
\hline
\end{tabular}

Berdasarkan hasil uji koefisien determinasi di atas menunjukkan bahwa pada sektor barang konsumsi, sektor keuangan, sektor pertambangan, sektor pertanian, serta sektor properti dan perumahan sebagian besar pada sektor tersebut perhitungan dari discretionary accruals bisa dijelaskan oleh variabel ROA dan variabel kontrol (OPM, OCF, Size, dan DE), sedangkan pada sektor yang lain seperti sektor aneka industri, sektor industri dasar dan kimia, sektor infrastruktur, utilitas, dan transportasi, serta sektor perdagangan, jasa dan investasi hanya menunjukkan sebagian kecil perhitungan discretionary accruals bisa dijelaskan oleh variabel ROA dan variabel kontrol (OPM, OCF, Size, dan DE), karena lebih banyak dipengaruhi oleh variabel lain. 
Uji F pada tabel 5 dilakukan untuk mengetahui apakah secara bersamasama variabel independen (ROA) dan variabel kontrol (OPM, OCF, Size, dan DE) dapat berpengaruh secara signifikan terhadap variabel dependen (DA).

Tabel 5. Uji F

\begin{tabular}{|c|c|c|}
\hline Sektor Utama & Model Regresi & Sig. \\
\hline Aneka Industri & DA & 0,031 \\
\hline Barang Konsumsi & DA & 0,777 \\
\hline Industri Dasar dan Kimia & DA & 0,141 \\
\hline Infrastruktur, Utilitas, dan Transportasi & DA & 0,099 \\
\hline Keuangan & DA & 0,016 \\
\hline Perdagangan, Jasa, dan Investasi & DA & 0,000 \\
\hline Pertambangan & DA & 0,270 \\
\hline Pertanian & DA & 0,001 \\
\hline Properti dan Perumahan & DA & 0,000 \\
\hline
\end{tabular}

Dari hasil uji F dapat ditunjukkan bahwa pada sektor aneka industri, sektor keuangan, sektor perdagangan, jasa, dan investasi, sektor pertanian, serta sektor properti dan perumahan terdapat pengaruh yang signifikan antara variabel independen ROA dan variabel kontrol, yang meliputi OPM, OCF, Size, dan DE terhadap variabel dependen DA sebagai ukuran keterlibatan perusahaan dalam melakukan manajemen laba (earnings management), sedangkan pada sektor utama lainnya tidak terdapat pengaruh yang signifikan antara variabel independen dan variabel kontrol terhadap variabel dependen.

Uji t pada tabel 6 berfungsi untuk melihat pengaruh signifikansi antara variabel dependen dengan variabel independen. Dalam pengambilan keputusan, Ha diterima jika nilai Sig. $\mathrm{T} \leq 5 \%$, sebaliknya Ha ditolak jika nilai Sig. T $\geq 5 \%$.

Tabel 6. Uji t

\begin{tabular}{|c|c|c|}
\hline Sektor Utama & Sig. & Hasil Penelitian \\
\hline Aneka Industri & 0,306 & Ditolak \\
\hline Barang Konsumsi & 0,628 & Ditolak \\
\hline Industri Dasar dan Kimia & 0,032 & Diterima \\
\hline
\end{tabular}




\begin{tabular}{|c|c|c|}
\hline Infrastruktur, Utilitas, dan Transportasi & 0,290 & Ditolak \\
\hline Keuangan & 0,177 & Ditolak \\
\hline Perdagangan, Jasa, dan Investasi & 0,555 & Ditolak \\
\hline Pertambangan & 0,816 & Ditolak \\
\hline Pertanian & 0,020 & Diterima \\
\hline Properti dan Perumahan & 0,741 & Ditolak \\
\hline
\end{tabular}

Dari hasil uji t di atas menunjukkan bahwa hanya 2 sektor yang hipotesisnya diterima, karena nilai tingkat signifikansi $\leq 0,05$, yang berarti terdapat pengaruh yang signifikan antara variabel dependen DA dan variabel independen ROA, sehingga dapat dikatakan profitabilitas berhubungan dengan earnings management pada kedua sektor tersebut, sedangkan 7 sektor utama lainnya menunjukkan bahwa tidak terdapat pengaruh yang signifikan antara variabel dependen DA dan variabel independen ROA, sehingga dapat dikatakan profitabilitas tidak berhubungan dengan earnings management pada sektor tersebut, dikarenakan krisis ekonomi Eropa tidak berdampak signifikan, sehingga perusahaan tersebut cenderung tidak melakukan earnings management.

Saat perusahaan di sektor industri dasar dan kimia mengalami kerugian akibat krisis ekonomi Eropa, perusahaan tersebut cenderung melakukan earnings management. Hasil penelitian ini sesuai dengan penelitian yang dilakukan oleh Wahyu (2009) yang menunjukkan bahwa pada sektor ini cenderung untuk melakukan earnings management, yaitu dengan menurunkan laba ketika perusahaan mengalami kerugian, dikarenakan sektor ini terkena dampak dari krisis ekonomi Eropa yang cukup signifikan, sehingga perusahaan cenderung untuk melakukan earnings management untuk mendapatkan bantuan dari pemerintah yang lebih besar jumlahnya.

Saat perusahaan di sektor pertanian mengalami kerugian akibat krisis ekonomi Eropa, perusahaan tersebut cenderung melakukan earnings management. Hasil penelitian ini sesuai dengan penelitian yang dilakukan oleh Wahyu (2009) yang menunjukkan bahwa ketika perusahaan di sektor ini mengalami kerugian, perusahaan cenderung akan menaikkan laba, sehingga dapat meningkatkan nilai Produk Domestik Bruto (PDB) yang pada akhirnya juga dapat meningkatkan harga saham dari perusahaan tersebut. 
Sektor industri dasar dan kimia serta sektor pertanian yang ikut melakukan earnings management sesuai dengan penelitian sebelumnya yang dilakukan oleh Selahudin, dkk. (2014) yang menunjukkan bahwa perusahaan di negara Thailand dan Malaysia juga cenderung melakukan earnings management pada saat perusahaan tersebut mengalami kerugian saat krisis ekonomi Eropa, yaitu tahun 2009-2012. Penelitian lain yang dilakukan oleh Lo (2010) juga mengungkapkan jika badan usaha mengalami kondisi yang buruk, seperti mengalami kerugian maka umumnya manajemen badan usaha akan melakukan earnings management.

Tetapi, 7 sektor lainnya, yaitu sektor barang konsumsi, sektor infrastruktur, utilitas dan transportasi, sektor pertambangan, sektor aneka industri, sektor keuangan, sektor perdagangan, jasa, dan investasi, serta sektor properti dan perumahan yang menunjukkan bahwa tidak ikut melakukan earnings management saat perusahaan mengalami kerugian sesuai dengan penelitian yang dilakukan oleh Iatridis dan Dimitras (2013) di negara Eropa yang menunjukkan bahwa perusahaan di Irlandia, Italia, dan Spanyol tidak ikut melakukan earnings management pada saat terjadi krisis ekonomi Eropa yang menyebabkan perusahaan di negara tersebut mengalami kerugian.

\section{KESIMPULAN DAN SARAN}

Dari hasil penelitian menunjukkan bahwa dari 9 sektor utama perusahaan di Indonesia, hanya 2 sektor yang terdapat hubungan antara profitabilitas dengan earnings management, yaitu pada sektor industri dasar dan kimia serta sektor pertanian, karena ketika perusahaan tersebut mengalami kerugian, perusahaan cenderung melakukan earnings management. Meskipun perusahaan yang terlibat earnings management sudah mengetahui konsekuensi dari praktik earnings management tersebut, namun tetap ada perusahaan di Indonesia yang melakukannya untuk keuntungan sendiri. Sektor yang terdapat hubungan antara profitabilitas dengan earnings management ini sesuai dengan penelitian yang dilakukan oleh Selahudin, dkk. (2014) serta Kusumawati dan Sasongko (2005) yang memberikan bukti empiris bahwa perusahaan publik yang mengalami kerugian akan melakukan earnings management, sedangkan sektor yang tidak 
terdapat hubungan antara profitabilitas dengan earnings management ini sesuai dengan penelitian yang dilakukan oleh Iatridis dan Dimitras (2013).

Penelitian ini diharapkan dapat membantu dan memberikan manfaat bagi pihak-pihak yang memiliki hubungan terhadap perusahaan maupun bagi peneliti selanjutnya. Bagi para investor sebaiknya sebelum memutuskan untuk menanamkan modalnya, lebih baik mempelajari terlebih dahulu laporan keuangan perusahaan secara seksama dan harus jeli dalam menangkap informasi yang disajikan, sehingga dapat mendeteksi upaya rekayasa yang dilakukan untuk menyembunyikan kondisi keuangan yang sebenarnya. Untuk pihak kreditor harus menyadari adanya praktik earnings management yang dilakukan oleh pihak manajemen perusahaan untuk memperoleh pinjaman, karena jika perusahaan mengalami kerugian, maka dikhawatirkan tidak mampu melunasi pinjaman yang dimiliki. Manajemen perusahaan pun harus menyadari bahwa earnings management tidak dapat dilakukan terus-menerus. Meskipun pihak manajemen akan memperoleh keuntungan, tetapi dampak buruk juga akan menimpa keberlangsungan hidup dari perusahaan tersebut. Menurunnya kepercayaan pihak eksternal terhadap kinerja manajemen akan berakibat pada menurunnya minat investor untuk menanamkan modal di perusahaan, sehingga juga akan berdampak pada penurunan permintaan dan harga saham.

Dalam melakukan penelitian ini, terdapat beberapa keterbatasan yang dihadapi, antara lain periode yang digunakan hanya dari tahun 2008-2011 yaitu saat krisis ekonomi Eropa, sektor industri yang digunakan hanya sektor utama, tidak memisahkan antara laporan keuangan perusahaan yang diaudit oleh KAP Big 4 dengan yang diaudit oleh KAP non Big 4, dan variabel independen yang digunakan hanya ada satu, yaitu variabel ROA. Dengan adanya keterbatasan tersebut, maka saran untuk penelitian selanjutnya adalah memperpanjang periode waktu penelitian sehingga memungkinkan penelitian berikutnya dapat menunjukkan hasil yang lebih konkrit, menggunakan seluruh sektor perusahaan termasuk sektor manufaktur dan sektor jasa, variabel independen yang digunakan lebih banyak dan memiliki hubungan yang signifikan dengan earnings management, serta memisahkan antara data laporan keuangan yang diaudit oleh KAP Big 4 dengan yang diaudit oleh KAP non Big 4. 


\section{DAFTAR PUSTAKA}

Ayers, B. C., Jiang, J., dan Yeung, P. E. 2006. Discretionary Accruals and Earnings Management: An Analysis of Pseudo Earnings Targets. The Accounting Review, 81, hal 617-652.

Baharuddin, Ishar, dan Satyanugraha. 2003. Persepsi Mahasiswa, Dosen, dan Praktisi Akuntan Indonesia terhadap Earnings Management, Vol. 5, No. 3.

Beneish, M.D. 2001. Earnings Management: A Perspective. Managerial Finance, Vol. 27, No. 12, hal 3-17.

Berita Investasi. 2012. Sektor Industri Barang Konsumsi. http://repository.usu.ac.id/bitstream/123456789/37258/5/Chapter\%20I.pdf (diunduh tanggal 28 Oktober 2015).

Dampak Krisis Keuangan Global terhadap Industri Properti di Indonesia. http://www.esaunggul.ac.id/article/dampak-krisis-keuangan-globalterhadap-industri-properti-di-indonesia-2/ (diunduh tanggal 28 Oktober 2015).

Dampak Krisis Keuangan Global terhadap Sektor Pertanian. http://www.litbang.pertanian.go.id/buku/konversi-fragmentasi-lahan/BAB II-1.pdf (diunduh tanggal 28 Oktober 2015).

Dechow, P.M., R.G. Sloan dan A.P. Sweeney. 1995. Detecting Earnings Management. The Accounting Review, Vol. 70, No. 2.

Dichev, I. dan P. Dechow. 2002. The Quality of Accruals and Earnings: The Role of Accrual Estimation Errors. The Accounting Review, Vol. 77 (Supplement), hal 35-59.

DuCharme, L., P. Malatesta dan S. Sefeik. 2004. Earnings Management, Stock Issues, and Shareholder Lawsuits. Journal of Financial Economics, 71(1), hal 27-49.

Efferin, S., Darmadji, S., dan Tan, Y. 2008. Metode Penelitian Akuntansi : Mengungkap Fenomena dengan Pendekatan Kuantitatif dan Kualitatif Edisi pertama. Yogyakarta, Jawa Tengah, Indonesia : Graha Ilmu.

Fachrudin, Khaira Amalia. 2008. Kesulitan Keuangan Perusahaan dan Personal Medan : USU Press.

Febriyanti, A., Sawarjuwono, T., dan Pratama, B. 2014. Manajemen Laba : Pro Kontra Pemaknaan antara Kreditur dan Debitur dalam Proses Pembiayaan Kredit, Vol.16 (1), hal 55-68.

Filip, A., \& Raffournier, B. (2012). The Impact of the 2008-2009 Financial Crisis on Earnings Management: The European Evidence. Illinois International Journal of Accounting Symposium, Ontario - Canada. 
Francis, J. dan J. Krishnan. 1999. Accounting Accruals and Auditor Reporting Conservation. Contemporay Accounting Research, Vol. 16, No. 1, hal 135-166.

Francis, J. dan K. Schipper. 1999. Have Financial Statements Lost their Relevance? Journal of Accounting Research, Vol. 37, hal 319-352.

Habib, A., Bhuiyan, B., Islam, A., 2013. Financial Distress, Earnings Management and Market Pricing of Accruals during the Global Financial Crisis. Journal of Finance 39 (2), hal 155-180.

Iatridis, G., Dimitras, A.I., 2013. Financial Crisis and Accounting Quality : Evidence from Five European Countries. Adv. Account.Inc. Adv. Int. Account. 29.

IDX. www.idx.co.id (diunduh Agustus 2015)

Jones, J., 1991. Earnings Management during Import Relief Investigations. J. Account. Res. 29, hal 193-228.

Kothari, S., Leone, A., \& Wasley, C. (2004). Performance Matched Discretionary Accrual Measures. Journal of Accounting and Economics, 39.

Lo, Eko Widodo. 2010. Manajemen laba : Suatu Sistesa Teori. Jurnal Akuntansi dan Manajemen Vol XVI No 3.

Mahmudi. 2001. Manajemen Laba (Earnings Management): sebuah Tindakan Etika Akuntansi. Jurnal Bisnis dan Akuntansi, Vol. 3, No. 2.

Martono. 2010. Pengertian Laporan Keuangan. http://repository.widyatama.ac.id/xmlui/bitstream/handle/123456789/279 /Bab\%202.pdf?sequence=7. (diunduh tanggal 29 Mei 2015).

Pertumbuhan Industri Dasar Kimia dan Pertanian Indonesia. http://repository.widyatama.ac.id/xmlui/bitstream/handle/123456789/270 /Bab\%201.pdf?sequence=6 (diunduh tanggal 28 Oktober 2015).

Scott, W. R. 2015. Financial Accounting Theory, Seventh Edition. Toronto : Pearson Education Canada.

Selahudin, N. F., N. B. Zakaria, Z. M. Sanusi, dan P. Budsaratragoon. 2014. Monitoring Financial Risk Ratios and Earnings Management : Evidence from Malaysia and Thailand. Procedia-Social and Behavioral Sciences, Vol. 145 : 51-60.

Srivastava, A. 2014. Why Have Measures of Earnings Quality Changed Over Time?. Journal of Accounting and Economics, Vol. 57 (2-3) : 196-217.

Sufren, dan N. Yonathan. 2014. Belajar Otodidak SPSS Pasti Bisa : Jakarta

Sugiri, S. 1998. Earnings Management : Teori, Model dan Bukti Empiris. Jakarta: Telaah.

Suhartanto, D. 2015. Pengaruh Ukuran Perusahaan, Profitabilitas, Leverage, Kepemilikan Publik, Perubahan Harga Saham dan Risiko Bisnis terhadap 
Manajemen Laba pada Perusahaan Publik Sektor Keuangan. Jurnal Ekonomi Bisnis, Vol. 20 (1) : 1-7.

Sulistiawan, D., Y. Januarsi, dan L. Alivia. 2011. Creative Accounting: Mengungkap Manajemen Laba dan Skandal Akuntansi, Jakarta : Salemba Empat.

SWA. www.swa.co.id (diunduh Oktober 2015).

Yahoo. www.finance.yahoo.com (diunduh September 2015). 